\title{
EASTERN EUROPEAN JOURNAL OF TRANSNATIONAL RELATIONS
}

2019 Vol. 3 No. 2

DOI: 10.15290/eejtr.2019.03.02.04

\section{Katarzyna Mróz ${ }^{1}$}

Lazarski University in Warsaw, Faculty of Law, Poland

\section{The Standards of Imprisonment in Penitentiary Isolation for People with Disabilities}

\begin{abstract}
In the Polish penitentiary reality, people with disabilities still face problems with organising prison sentences in prisons. The need to ensure a proper and coherent system, taking into account the needs of people with various dysfunctions, is a challenge for states and societies. The detention of people with disabilities is a contribution to the discussion on effective methods and effective instruments of social policy implemented by the state, enabling the process of social rehabilitation and reintegration. This paper contains a reflection on the relationship between the European Prison Rules and the Polish law regulating the execution of imprisonment and penitentiary practice.
\end{abstract}

Keywords: disability, penitentiary unit, prison rules, therapeutic effects

\section{Introduction}

Disability is a multifaceted phenomenon, requiring a look at it from the perspective of the rules of social organization and broadly understood culture, as well as the properties of the penitentiary and political system. The presence of a disability in the public space is a challenge for many state institutions and bodies, which determine the conditions of "visibility (or rather invisibility) of what is different" (Godlewska-Byliniak \& Lipko-Konieczna 2016, p. 1). Disability issues have been widely discussed and analysed. In the penitentiary reality, we are still dealing with an exploratory deficit, suggesting the need to conduct in-depth analyses of the impact of an isolated imprisonment sentence on people with disabilities. The

$1 \mathrm{PhD}$ student at the Lazarski University in Warsaw, Faculty of Law. ORCID: https://orcid. org/0000-0003-4775-7767. E-mail: katarzyna.iwona.mroz@gmail.com 
subject of this article is the issue of serving prison sentences in penitentiary units by such persons, who constitute a significant part of the prison population in Poland. The study will present issues related to the penitentiary reality of the prisoners with all possible types of disabilities and proposals for solutions that could contribute to a more effective change in the functioning of these prisoners, which would stop them from returning to crime (Braun, 2013, p. 131).

The Polish penitentiary system still faces problems related to the organization of imprisonment for people with disabilities (Fajfer-Kruczek, 2017, p. 244). The idea of absolute equality and social justice, which is the goal of all penitentiaries acting in the name of the social good, remains an illusory idea (Chrzanowska, 2013, p. 63). Knowledge of the functioning of people with disabilities in prison is still low, which leads to degrading treatment and discrimination against them (Zima-Parjaszewska, Wołowicz-Ruszkowska, Kurowski, Orzechowski, \& Buchholtz, 2015, p. 7). The aim of the discussion is to highlight the problems concerning the processes of adapting penitentiary isolation to people with disabilities. The author's assumption is to verify not only the penitentiary situation of this category of prisoners but also to determine the legitimacy of the placement in the penitentiary unit. These considerations are supplemented by selected theoretical concepts of action to improve the organization of imprisonment for people with disabilities and the adequate penitentiary impact on them (Malinowska, 2018, p. 9-10). The presented text requires a thorough assessment of the implementation by the state of the standards on the application of imprisonment for people with disabilities.

Recent years have brought enormous changes both in the perception of people with disabilities, in the definition of disability and in the definition of the responsibilities of the state towards this group of society. The decisive influence on the changes has been the activities at the international level, which set the standards for the participation of people with disabilities in every aspect of social life (ZimaParjaszewska, Wołowicz-Ruszkowska, Kurowski, Orzechowski, \& Buchholtz, 2015, p. 7), and national, relevant to the conduct of detention and the prospects for social rehabilitation at liberty of persons with disabilities (Fajfer-Kruczek, 2017, p. 241). The approximation of knowledge of the European Prison Rules in Poland is essential to determine the actions of the national legislator, adapting the Polish standards of criminal law and implementing the European Penitentiary Rules to the Polish Penitentiary Rules (Płatek, 1997, p. 167).

\section{The execution of sentences of imprisonment in accordance with the European Prison Rules}

The idea of creating international standards for dealing with prisoners, which set benchmarks for both the legislator and practice, appeared during the first penitentiary 
congress in London and evolved at the following ones: in Stockholm (1878) and in Rome (1885) (Płatek, 1997, p. 168). The original version of the European Prison Rules (Recommendation Rec (2006)2 of the Committee of Ministers to the Member States of the Council of Europe on European Prison Rules (Adopted by the Committee of Ministers on 11 January 2006 at the 952nd meeting of delegates ${ }^{2}$ ) was the Minimum Rules, which were the model of the United Nations for the lawful conduct of prisoners. The Standard Minimum Rules for the Treatment of Prisoners (RM) were approved by Resolution 663 CI (XXIV) of 31 July 1957 in the version adopted by Congress ${ }^{3}$. In the introductory remarks of the Rules it was stated that the purpose of the Rules was not to define in detail a model prison system but only to define positive rules and practices for dealing with prisoners (Platek, 1997, p. 170). It was stressed that the Rules adopted contain the minimum rights and freedoms for prisoners and the minimum requirements for the prison administration, which are considered appropriate to protect prisoners against ill-treatment (Płatek, 1997, p. 168).

In 1973, the Council of Europe developed its own rules for dealing with detainees. The Council of Europe's Standard Minimum Rules for the Treatment of Prisoners were adopted on 14 February 1973 in Resolution (73)5 (Płatek, 1997, p. 171). The UN Minimum Rules require penitentiary staff to treat mentally disabled prisoners differently, thus preventing their disability from worsening and preparing them for later life in the society (Gordon, 2006, pp. 207-216). Social change, leading not only to changes in social behaviour and aspirations but also to changes in the traditional forms of crime and views on crime (Płatek, 1997, p. 172), led the Committee of Ministers of the Council of Europe to adopt Recommendation R(87)3 to the Member States at its 404th meeting of the Ministers' Deputies on 12 February 1987. The Annex to Recommendation R(87)3 is the European Prison Rules, a revised version of the European Standard Minimum Rules for the Treatment of Prisoners. The idea of creating a policy of execution in an open society (see Gonsa, 1992, p. 13-19) has contributed to the adoption of a new philosophy of execution of prison sentences

2 Rekomendacja Rec (2006)2 Komitetu Ministrów do państw członkowskich Rady Europy w sprawie Europejskich Reguł Więziennych (Przyjęta przez Komitet Ministrów w dniu 11 stycznia 2006 r. na 952 posiedzeniu delegatów) [Recommendation Rec (2006)2 of the Committee of Ministers to the Member States of the Council of Europe on the European Prison Rules (Adopted by the Committee of Ministers on 11 January, 2006 on the 952 Meeting of Delegates]. Retrieved from https://bip.sw.gov.pl/SiteCollectionDocuments/CZSW/prawaczl/document.pdf [accessed on 13.08.2019].

3 Standard Minimum Rules for the Treatment of Prisoners Adopted by the First United Nations Congress on the Prevention of Crime and the Treatment of Offenders, held at Geneva in 1955, and approved by the Economic and Social Council by its resolutions $663 \mathrm{C}$ (XXIV) of 31 July 1957 and 2076 (LXII) of 13 May 1977. Retrieved from https://www.unodc.org/pdf/criminal_ justice/UN_Standard_Minimum_Rules_for_the_Treatment_of_Prisoners.pdf [accessed on 13.08.2019]. 
and new objectives for the penitentiary administration (Neale, 1992, p. 4-6). What the Minimum Rules recommended, stating that "... in shaping the regime of a given establishment, the aim should be to reduce all differences between prison life and life at liberty, so as not to contribute to the weakening of prisoners' responsibility or respect for their dignity as human beings" (Part II, 60(1)). In Part I the European Prison Rules stressed making this recommendation a fundamental principle. The rules are based on the principles of humanity, morality, justice and respect for human dignity. "For human dignity requires that in all circumstances everyone be treated in a particular way which limits freedom of choice, not because they deserve to be treated in some way, but simply because they are human" (Środa, 1994, p. 156-158).

The original version of the European Prison Rules (1987) was substantially amended in 2006 on the basis of the Recommendation Rec (2006) 2 of the Committee of Ministers of the Member States of the Council of Europe on European Prison Rules, adopted by the Committee of Ministers on 11 January 2006 at its 952nd meeting of delegates. The Council of Europe explicitly stated that Recommendation 87(3) of 1987 replaces Recommendation Rec(2006)2 (Nikołajew, 2013, p. 116). The Council of Europe, when extending the guidelines contained in the European Prison Rules, has taken into account the changing reality of prisons and the experience gained from the case law of the European Court of Human Rights and the recommendations of the Committee for the Prevention of Torture and Inhuman and Degrading Treatment or Punishment (Nowicki, 2009, p. 111). As Monika Płatek rightly points out, the 2006 European Prison Rules mean a "breakthrough in the approach to imprisonment. They admit straightforwardly that imprisonment is harmful. However, since at the present stage of civilisational development we do not resign from this punishment, its implementation should be carried out in a way that minimises damage" (Płatek, 2008, p. 3.). According to Rule 6, all deprivation of liberty should be organised in such a way as to facilitate the social reintegration (readaptation) of persons deprived of their liberty from the outset (Myrna, 2009, p. 232). Regulation 12 provides that persons suffering from mental illness and those whose mental condition is incompatible with their imprisonment should be detained in institutions specifically designed for that purpose (Regulation 12.1). However, if such persons are exceptionally detained in a penitentiary, there are special rules that take into account their status and needs (rule 12.2). The importance of the 2006 European Prison Rules goes beyond penitentiary policy and affects both penal policy and social policy (Płatek, 2008, p. 3).

The new codification of the executive criminal law in Poland is the result of the practical implementation of the guidelines of the Council of Europe contained in the Standard Minimum Rules for the Treatment of Prisoners and the European Prison Rules of 1987 and 2006. With regard to a disabled person in custody, attention should be paid to the conditions that meet his or her particular needs. The Prison Administration shall take all reasonable steps and arrangements to ensure that 
prisoners with physical, mental or other disabilities have full and effective access to prison life on fair terms. ${ }^{4}$ Bearing in mind that imprisonment is a punishment in itself, the rigour imposed on convicts should not increase the suffering associated with imprisonment. Imprisonment should be carried out in such material and moral conditions as to ensure respect for human dignity. This principle reflects Article 4 of the Executive Penal Code (1997), which provides that penalties, punitive, protective and preventive measures shall be carried out in a humane manner with respect for the human dignity of the sentenced person. Torture or inhuman or degrading treatment or punishment of the sentenced person shall be prohibited (Executive Penal Code, 1997).

"States have a duty to take appropriate measures to ensure effective protection for persons particularly in need of it and to take reasonable steps in response to any improper treatment of which the authorities are aware or could reasonably have been aware" (Vincent v. France, 2006, par. 43). Measures should be taken within a reasonable time. The European Court of Human Rights grants national authorities a certain margin of discretion as to what kind of procedural mechanisms should be used to ensure that a person with a disability is guaranteed "good administration of justice and to protect health of the person concerned" (see Shtukaturov v. Russia, 2008, par. 68; R.P. and others v. United Kingdom, 2012, par. 65). The Court has repeatedly emphasised that Article 3 of the Convention for the Protection of Human Rights and Fundamental Freedoms (1950) prohibits the inhuman or degrading treatment of anyone entrusted to the care of the authorities, whether the restriction of liberty is imposed in the context of criminal proceedings or admission to an institution for the protection of the life or health of the person concerned (Stanev v. Bulgaria, 2012). The European Court of Justice stresses that if the authorities decide to place a person with a disability in detention, they must take special care in guaranteeing such conditions as correspond to the special needs resulting from a disability (see Asalya v Turkey.2014, par. 40 and the case law cited therein).

\section{Persons with disabilities in penitentiary isolation}

The stay in detention centres and prisons of persons temporarily arrested and persons with intellectual disabilities raises a number of problems. People with mental or intellectual disabilities are a particularly vulnerable group of prisoners due to their helplessness and lack of understanding of their own situation. The fact that this problem is a serious one is proved not only by the studies carried out to assess the mental health of prisoners in prisons in many countries of the world but also by

$4 \quad$ Lt. Rule 5 of the Mandela. 
incidental cases of specific behaviour of prisoners - mentally ill or with intellectual disabilities (Dawidziuk \& Mazur, 2017, p. 17).

The model of separate treatment of prisoners with intellectual disabilities, which is currently being implemented, is the result of many years of practical experience. In the initial period of shaping the Polish penitentiary system, it was not considered necessary to establish special prisons or wards for prisoners with disabilities (Malinowska, 2018, p. 9-10). The first changes took place as a result of international penitentiary congresses, during which the conditions of detention were to be adjusted to the personal needs of prisoners (Pawlak, 2007, p. 55-56). The first group of convicts, whose sentences were individualized, were people with mental illnesses (Pawlak, 2007, p. 58). The way of dealing with disabled prisoners was comprehensively regulated only in the late 1930s, when the Act of 26 July 1939 on the organization of the prison system was adopted. ${ }^{5}$ In the People's Republic of Poland, the issue of disabled prisoners was addressed at the end of the 1950s. As in the previous period, attention was paid to people with mental disorders and diseases as soon as possible. The situation of disabled prisoners began to improve gradually at the end of the 1980s. A number of innovations in the area of separate treatment of prisoners requiring therapy were introduced in the Regulation of the Minister of Justice of 2 May 1989 on the regulations governing the execution of sentences for imprisonment. ${ }^{6}$ Among the convicts, persons with mental disorders, mental disabilities, addictions and physical disabilities were separated, and some penitentiary interactions provided adaptations to their needs and limitations (Braun, 2013, p. 131).

In order to ensure that the conditions necessary for prisoners to function in prison are in place, they have begun to be classified. In order to ensure that the conditions necessary for the functioning of the penitentiary are in place, the prisoners began to be classified, and in order to ensure that the conditions necessary for the functioning of the prison system are in place. Currently, the problem of executing prison sentences for people with disabilities is regulated by the Act on the Criminal Executive Code. In the classification of detainees there are three systems of imprisonment: the regular system, the programmed impact and the therapeutic system. The indication of the three possible systems of detention is based on the assumption that the intended effect on persons deprived of their liberty will be achieved only if, having known and understood the criminogenic factors and made the diagnosis, an appropriate system of detention is chosen, together with the appropriate means of exerting influence (Dąbkiewicz, 2012, p. 280). The criteria to be taken into account in the division shall in particular be age, previous serving of a custodial sentence, intentional or negligent

$5 \quad$ Journal of Laws No. 68, item 457.

6 Journal of Laws No. 31, item 166. 
conduct, and the state of physical and mental health. Such classifications shall be based in particular on personal cognitive research.

From the perspective of the considerations conducted, it is worth paying particular attention to the legally guaranteed possibility of serving a sentence of imprisonment in the therapeutic system. Pursuant to Article 96 of the Executive Penal Code, to serve the sentence of imprisonment in the therapeutic system, convicts may be classified with non-psychotic mental disorders (including convictions for crimes under Articles 197-203 of the Penal $\mathrm{Code}^{7}$, which were committed in connection with disorders of sexual preferences), as well as with mental impairment, addiction to alcohol or other intoxicants or psychotropic substances, as well as convicts with physical disability, who require specialist influence, in particular in the field of psychological, medical and rehabilitation care (Lelental, 2012, p. 326). In the National Preventive Mechanism Report of 2015, it was indicated that "[...] it is doubtful whether the mere fact of separating a unit of one type intended for prisoners with different disorders and intellectual capabilities should be taken into account. Such a situation significantly hinders the development of an offer of therapeutic interactions adequate to the often very different needs of persons referred to the ward and requires the staff to simultaneously have knowledge of, inter alia, oligophrenopedagogy, sexology or psychopathology"s.

Currently, there are 23 therapeutic wards in the penitentiary system in Poland. According to the data of the Central Board of Prison Service, at the end of 2016 there were 1507 people in these wards .

The punishment for imprisonment in the therapeutic system shall be served in wards of a specified specialty (Postulski, 2016, p. 706) aimed at providing detainees with appropriate assistance and support adequate to their individual needs and determined primarily by the type of disability concerned (Malinowska, 2018, p. 9). On the basis of current regulations, in the case of prisoners with disabilities, the aim of the therapeutic actions taken against them is: to prevent the deepening of pathological personality traits, to restore psychological balance, to shape the ability of social coexistence (applies to mentally disabled people), to prevent the deterioration of their state of health (applies to physically disabled people), as well as to prepare them for independent living (Braun, 2013, p. 136). During the execution of a sentence of imprisonment in the therapeutic system, the need to prevent the development of pathological personality traits, to restore psychological balance and to shape the ability of social coexistence and preparation for independent living in

7 Act of 6 June 1997 - Penal Code (Journal of Laws of 2018, item 1600).

8 Visits to the National Therapeutic Unit Prevention Mechanism for Persons with NonPsychotic Psychiatric Disorders or Mental Handicap and for Persons in Detention, Office of the Ombudsman, Warsaw 2014. Retrieved from www.rpo.gov.pl [accessed on 10.12.2017].

9 Annual Statistical Information for 2016. Ministry of Justice. Central Board of Prison Service. Retrieved from www.sw.gov.pl [accessed on 10.12.2017]. 
relation to a particular convicted person shall be taken into account in particular (Lelental, 2012, p. 326).

Prisoners with disabilities shall be subject to all possible social rehabilitation impacts guaranteed by law (Braun, 2013, p. 136). In accordance with the Regulation of the Minister of Justice of 14 August 2003 on the manner of conducting penal interactions in penal institutions and detention centres ${ }^{10}$, specialist interactions may also include convicts, including the disabled serving their sentences in a therapeutic system outside of designated wards (Dąbkiewicz, 2012, p. 442). This applies in particular to convicts with respect to those a psychologist has stated in an opinion or a psychological-penitentiary ruling that it is possible to carry out individualised penitentiary work outside the ward in question.

Currently, out of almost 78,000 prisoners in Polish penitentiary institutions, over 4,000 disabled prisoners are serving prison sentences, which accounts for almost $20 \%$ of the total prison population (Szlęzak-Kawa, 2014, p. 13). It is estimated that in conditions of freedom this rate is $12.2 \%$. In most provinces of Poland there are penitentiary units which are adapted to the needs resulting from the inclusion of convicts with disabilities. For years, the Ministry of Justice has been undertaking actions aimed at full implementation of the principle of humanity and respect for human dignity. The general directions of administrative supervision in 2018 established by the Minister of Justice emphasise the issue of respecting the rights of prisoners with physical or intellectual disabilities and mental disorders, with particular emphasis on the state of medical, psychological and sanitary care, as well as living conditions in which they are detained, including barriers hindering the proper functioning of prisoners with disabilities ${ }^{11}$. Ordinance No. 19/16 of the Director General of the Prison Service of 14 April 2016 on the detailed rules of conducting and organizing penitentiary work and the scope of activities of officers and employees of penitentiary and therapeutic departments and penitentiary departments normalized the manner of conducting penitentiary interactions, taking into account the special needs of disabled prisoners and the need to ensure their treatment in a manner that prevents discrimination. Taking into account the Charter of Rights of Persons with Disabilities ${ }^{12}$ adopted on 1 August 1997 by the Polish Sejm and the Convention on the Rights of Persons with Disabilities ${ }^{13}$ ratified by Poland on 6 September $2012^{14}$, persons with disabilities deprived of their liberty should be

10 Journal of Laws No. 151, item 1469.

11 Letter from the Minister of Justice to the Ombudsman of 14.04.2018, DWMPC-III-850-2/18, p. 7.

12 M.P. of 1997, No. 50, item 475.

13 Convention on the Rights of Persons with Disabilities. Resolution adopted by the General Assembly (UN) 61/06, A/RES/61/106 from 13 December 2006. Retrieved from: http://www. unic.un.org.pl/dokumenty/Konwencja_Praw_Osob_Niepelnosprawnych.pdf [accessed on 10.11.2019].

14 Journal of Laws of 2012, item 1169. 
allowed to live independently and participate fully in all areas of their lives in the environment created by the place of their detention.

The Convention on the Rights of Persons with Disabilities is a great and important step by the international community towards defining and recognizing a modern approach to disability - from a caring and charitable approach to creating a society and environment open to all, inclusive and equal opportunities, based on human rights. The Convention lays down minimum requirements for the rights of persons with disabilities and indicates the objectives to be pursued. The aim of the Convention is to promote, protect and ensure the full and equal enjoyment of all human rights and fundamental freedoms by all persons with disabilities on an equal basis with all other citizens. The rights covered by the Convention apply to all persons with disabilities, regardless of the type and degree of disability. The Convention is an important legacy of humanity. It is not only a normative act, but also an educational document that brings together in one place in an orderly manner the fundamental values, rights and directions of solutions affecting the quality of life of every disabled person and his place in society. People with disabilities, regardless of their type and degree of disability, face difficulties in adapting to prison conditions. One of the significant barriers to the participation of people with disabilities in public space, especially in penitentiary units, is the infrastructure of the space in which they function. Currently, there are several dozen penitentiary units in Poland with objectives adapted to the needs of people with disabilities. The purpose of these units is a response to the need for a specialized way of penitentiary work, based on individual and group therapy, as well as occupational therapy. A few years ago, the Central Board of Prison Service admitted that most of the 156 penitentiary units in Poland are unsuitable for detainees and prisoners with reduced mobility (Korona, 2013, p. 17). Only less than one third of the companies were more or less prepared to accept such people. The problem was the lack of adaptation of conditions to their needs - lack of ramps or elevators. In addition, there were an insufficient number of specialist rehabilitation and physiotherapy laboratories, which prolonged the waiting time of prisoners for rehabilitation procedures and even the need to escort them to another unit (Stanisławski, 2008). At present, many units are undergoing modernisation activities, so the situation is better than it was years ago. As far as the issue of adapting buildings to the needs of disabled people is concerned, in the organizational units of the penitentiary gradually - in order to adapt them to real needs - actions are undertaken for the benefit of disabled people, aimed at eliminating architectural barriers, both in existing buildings, newly built buildings and in the adjacent $\operatorname{areas}^{15}$.

Another important issue that affects the functioning of people with disabilities in penitentiary institutions is housing conditions and the possibility of adapting

15 Letter from the Minister of Justice to the Ombudsman, p. 4. 
private space to the specific needs of people with disabilities. The assessment of the availability of square meters per person does not yet determine good or bad housing conditions, as it also includes other very important factors, such as access to running water, bathrooms and private space (Książkiewicz, 2011, p. 37). Architectural barriers for people with disabilities, insufficient target area, are just some of the irregularities identified in custody and prisons (Rojek, 2018). Another important issue is the insufficient number of psychologists in penitentiary units. It is estimated that there are even 200 detainees per one psychologist (Rojek, 2018). In the case of a person with a disability, the stay in a penitentiary is not infrequently incompatible with the purpose of executing a sentence of imprisonment or even constitutes a threat to the life and health of the detainee.

\section{Conclusion}

The problem of keeping people with disabilities in penitentiary units has existed for a long time. The penitentiary status of such persons has changed over the years. During the evolution of the penitentiary system, appropriate actions were taken to ensure appropriate classification of convicts, including persons with disabilities, which was to allow not only to serve the sentence imposed in accordance with applicable law, but also to take appropriate educational and therapeutic measures. Recent years have brought many changes in the search for effective forms of imprisonment in penitentiary institutions by persons with various dysfunctions, and at the same time have confirmed the right of persons with disabilities to full participation in social life on the basis of equality with others (Zima-Parjaszewska, Wołowicz-Ruszkowska, Kurowski, Orzechowski, \& Buchholtz, 2015, p. 31). It is increasingly being observed in the state and in public life that people with disabilities are treated as 'full citizens and valued members of society' (Sierpowska $\&$ Kogut, 2010, p. 11). The creed of modern penitentiary is a statement that "a man always enters prison, but a criminal always remains behind his gate" (Gajdus, B., Gronowska, 1998, p. 18).

A good criminal policy is a kind of support, not a privilege, but a right to which everyone is entitled (Książkiewicz, 2011, p. 2). "The measure of quality of life in a community is to a large extent the care it provides for the most vulnerable and needy and respect for their human dignity. Only when the rights of the weakest are recognized can society claim to be founded on the foundation of law and justice" (John Paul II, 2004). Disability is not just a competence of a person, but a set of social and physical conditions that cause difficulties and limitations for a person with a disability (Zima-Parjaszewska, Wołowicz-Ruszkowska, Kurowski, Orzechowski, \& Buchholtz, 2015, p. 19). "In order to implement the principles of equality and 
social justice, persons with disabilities should be granted additional benefits and specific assistance by public authorities" (Sierpowska \& Kogut 2010, p. 11).

Proper assistance is conditioned by the knowledge of the specificity of the functioning of people with disabilities in penitentiary units. The therapeutic program, addressed to people with various dysfunctions, is the coordination of methods of therapeutic interactions, including their superiority over other penal interactions, while shaping the environment of convicts, the individualization of methods and means of therapeutic interactions in relation to the psychophysical properties of convicts, shaping the sense of responsibility for their fate, facilitating adaptation to the conditions of penitentiary and effective functioning outside it, as well as stimulating faith in the ability to lead a satisfactory life after leaving prison (Korona, 2013, p. 20). However, social attitudes towards the changes being made still effectively block the real opening of the social model of disability (PodgórskaJachnik, 2015). "Being Other [...] often leads to an objective inability to use the rights and system facilities of a community, access to which is formally guaranteed to everyone and everyone. This means that an individual or group difference causing some kind of isolation or stigmatization or even marginalization creates a potential opportunity to generate an exclusive process" (Dziewięcka-Bokun, 2003, pp. 207215). It is appropriate to agree with Ludmila Dziewiecka-Bokun that ecclesia in the sphere of legal systems is caused in particular by the law itself (Dziewięcka-Bokun, 2003, p. 215).

Despite many years of discussions on the shape of the state's care and integration policy towards people with disabilities and numerous actions taken in this respect, too much of this social group remains hostage to stereotypes and myths. The protection of the rights of people with disabilities serving imprisonment is a particular challenge for contemporary society and the Polish state. "The primary purpose of a public authority (state) is to care for the common good" (Stahl, 2007, pp. 96-97). The common good is to serve the good of the individual, his creation, extension and deepening (Boć, 2009, pp. 152-153). In the opinion of Jan Boć: "a certain common good does not have to affect all citizens, but it cannot be shared or selectively acted upon" (Boć, 2009, p. 153). State measures often do not require additional costs, but only a little bit of goodwill and individual approach (Witkowska, 2016), p. 104. "Understanding the need for equal standards of living for people with disabilities and disabilities is the greatest effect of social changes at the turn of the century" (Krause, 2009 , p. 11). Thanks to the ongoing social and cultural changes and changes in social awareness, people with disabilities are increasingly able to fully meet their life needs and goals in prisons and detention centres (Dykcik, 2009, p. 25-58).

Given that deprivation of liberty is an exceptionally difficult situation for certain vulnerable persons, such as minors, elderly people, pregnant women and persons suffering from severe mental or physical disorders or disabilities, Member States should ensure appropriate detention conditions for each of these categories 
of persons. Guaranteeing decent and humane conditions of detention is a first step to respect the rights of prisoners with disabilities. Although Polish legislation on the rights of prisoners with disabilities is broadly in line with European and UN standards for the provision of adequate conditions in prisons, the fundamental rights of persons with disabilities deprived of their liberty are still not fully protected. An adequate approach by prison staff and the penitentiary administration as a whole will be a prerequisite for ensuring humane conditions in prisons and thus for effective action to improve the management of prisons, the successful rehabilitation of prisoners and to reduce the risk of radicalisation and repeat offences. Respect for the rules on the detention of prisoners with disabilities under international law instruments and Council of Europe standards will be a reminder that imprisonment does not mean deprivation of dignity.

\section{REFERENCES}

Act of 26 July 1939 on the organization of the prison system. Journal of Laws No. 68, item 457.

Act of 6 June 1997 - Executive Penal Code. Journal of Laws of 2019, item 676.

Act of 6 June 1997 - Penal Code. Journal of Laws of 2018, item 1600.

Boć, J. (2009). Z refleksji nad dobrem wspólnym [From the reflection on the common good]. In J. Boć \& A. Chajbowicz (Eds.), Nowe problemy badawcze $w$ teorii prawa administracyjnego [New research problems in the theory of administrative law] (pp. 151-161). Wrocław: Kolonia Limited.

Braun, P. (2013). Osoba niepełnosprawna w izolacji penitencjarnej [Disabled person in penitentiary isolation]. Niepetnosprawność - Zagadnienia, Problemy, Rozwiqzania, II (7), 129-151.

Charter of Rights of Persons with Disabilities. M.P. of 1997, No. 50, item 475.

Chrzanowska, I. (2013). Niepełnosprawność a zagrożenie marginalizacją i wykluczeniem. Rozważania w kontekście teorii underclass [Disability and the threat of marginalisation and exclusion. Considerations in the context of the underclass theory]. Studia Edukacyjne, (25), 63-74.

Convention for the Protection of Human Rights and Fundamental Freedoms, signed signed in Rome on 4 November 1950, amended by Protocols Nos. 3, 5 and 8 and supplemented by Protocol No. 2. Journal of Laws of 1993, No. 61, item 284.

Convention on the Rights of Persons with Disabilities. Journal of Laws of 2012, item 1169.

Convention on the Rights of Persons with Disabilities. Resolution adopted by the General Assembly (UN) 61/06 A/RES/61/106 from 13 December 2006. Retrieved from: http://www.unic.un.org. pl/dokumenty/Konwencja_Praw_Osob_Niepelnosprawnych.pdf [accessed on 10.11.2019].

Dąbkiewicz, K. (2012). Kodeks karny wykonawczy. Komentarz. [The Criminal Executive Code. Comments]. Warsaw: Wolters Kluwer.

Dawidziuk, E., \& Mazur, M. (Eds.) (2017). Osoby z niepetnosprawnościq intelektualnq lub psychicznq osadzone w jednostkach penitencjarnych. Z uwzględnieniem wyników badań przeprowadzonych przez pracowników Biura Rzecznika Praw Obywatelskich [People with intellectual or mental 


\section{THE STANDARDS OF IMPRISONMENT IN PENITENTIARY ISOLATION...}

disabilities imprisoned in penitentiary units. Taking into account the results of research conducted by the employees of the Office of the Ombudsman]. Warsaw: Biuro Rzecznika Praw Obywatelskich.

Dykcik, W. (2009). Interkulturowe i makrospołeczne konteksty stereotypów w działalności praktycznej $\mathrm{z}$ osobami niepełnosprawnymi [Intercultural and macrosocial contexts of stereotypes in practical activities with people with disabilities]. Niepetnosprawność, (1), 25-57.

Dziewięcka-Bokun, L. (2003). Ekskluzja społeczna jako problem polityki społecznej [Social exclusion as a problem of social Policy]. In L. Dziewięcka-Bokun \& K. Zamorska (Eds.), Polityka spoteczna. Teksty źródtowe [Social policy. Reference texts] (pp. 209-215). Wrocław: Wydawnictwo Uniwersytetu Wrocławskiego.

Fajfer-Kruczek, I. (2017). Adaptacja osób z niepełnosprawnością intelektualną do izolacji penitencjarnej - stan obecny oraz możliwe ukierunkowanie działań w zakresie modyfikacji istniejących rozwiązań [Adaptation of people with intellectual disabilities to penitentiary isolation - the current state and possible targeting of activities in the field of the modification of existing solutions]. Studia Pedagogiczna, vol. L, 241-243.

Gajdus, B., \& Gronowska, B. (1998). Europejskie standardy traktowania więźniów. Rekonstrukcja standardów oraz ich znaczenie dla polskiego prawa i praktyki penitencjarnej. Zarys wyktadu [European standards for the treatment of prisoners. Reconstruction of standards and their importance for Polish law and penitentiary practice. Outline of the lecture]. Torun: Dom Organizatora.

Godlewska-Byliniak, A., \& Lipko-Konieczna, J. (2016). Publiczne - prywatne: teatralna gra $\mathrm{z}$ niepełnosprawnością [Public - private: theatrical game with disabilities]. Polish Theatre Journal, (2), 1-18.

Gonsa, H. (1992). The Organisation of Imprisonment, the Treatment of Prisoners and the Preparation of Prisoners for Release. Prison Information Bulletin, (16), 13-19.

Gordon, M. (2006). Resocjalizacja skazanych z zaburzeniami psychicznymi- możliwości i ograniczenia [The rehabilitation of convicts with mental disorders - possibilities and limitations]. In H. Machel (Ed.), Wykonywanie kary pozbawienia wolności w Polsce - w poszukiwaniu skuteczności [The execution of the sentence of imprisonment in Poland - in search of effectiveness] (pp. 207-216). Gdańsk: Wydawnictwo Uniwersytetu Gdańskiego.

John Paul II (2004). Ludzie najsłabsi i najbardziej potrzebujacy w życiu społeczeństwa. Przestanie: Godność i prawa osoby z upośledzeniem umystowym [The weakest and most needy people in society. Message: Dignity and rights of the mentally handicapped.]. Retrieved from https:// opoka.org.pl/biblioteka/W/WP/jan_pawel_ii/przemowienia/uposledzenie_05012004.html [accessed on 1.09.2014].

Judgment of the European Court of Human Rights of 12.01.2012 in the case of Stanev v. Bulgaria, application no. 36760/06.

Judgment of the European Court of Human Rights of 15.04.2014 in Asalya v Turkey, application no. $43875 / 09$.

Judgment of the European Court of Human Rights of 24.10.2006 in Vincent v. France, application no. $6253 / 03$.

Judgments of the European Court of Human Rights of 27.03.2008 in the case of Shtukaturov v. Russia, complaint no. 44009/05. 


\section{EASTERN EUROPEAN JOURNAL OF TRANSNATIONAL RELATIONS}

Judgments of the European Court of Human Rights of 9.10.2012 in case R.P. and others v. United Kingdom, application no. 38245/08.

Konwencja o prawach osób niepełnosprawnych, sporządzona w Nowym Jorku dnia 13 grudnia 2006 r. [Convention on the Rights of Persons with Disabilities, done in New York on 13 December 2006]. Journal of Laws of 2012, item 1169.

Korona, K. (2013). Sytuacja osób niepełnosprawnych przebywających w polskich zakładach karnych [The situation of disabled people in Polish prisons]. Zeszyty Naukowe WSSP, 16, 11-23.

Krause, A. (2009). Teoretyczne i empiryczne problemy pedagogiki specjalnej. Zarys obszarów badawczych [Theoretical and empirical problems of special pedagogy. Outline of research areas]. Niepetnosprawność. Pótrocznik Naukowy. Teoretyczne i metodologiczne konteksty pedagogiki specjalnej, 1(1), 9-24.

Książkiewicz, I. (2011). Analiza problemów osób niepetnosprawnych na terenie powiatu pułtuskiego [Analysis of the problems of disabled people in Puttusk county]. Pułtusk: Akademia Humanistyczna im. Aleksandra Gieysztora.

Lelental, S. (2012). Kodeks karny wykonawczy. Komentarz [The Criminal Executive Code. Comments]. Warsaw: C.H.Beck.

Letter from the Minister of Justice to the Ombudsman of 14.04.2018, DWMPC-III-850-2/18.

Malinowska, S. (2018). Wybrane aspekty odbywania kary pozbawienia wolności przez osoby z niepełnosprawnością intelektualną [Selected aspects of imprisonment for people with intellectual disabilities]. Edukacja Humanistyczna, 1(38), 9-19.

Ministry of Justice. Central Board of Prison Service. Annual Statistical Information for 2016. Retrieved from www.sw.gov.pl [accessed on 10.12.2017].

Myrna, B. (2009). Wykonanie kary pozbawienia wolności w świetle Europejskich Reguł Więziennych z 2006 r. Podstawowe zasady, zakres i zastosowanie przedmiotowych reguł [Execution of a sentence of imprisonment under the 2006 European Prison Rules Basic principles, scope and application of these rulet]. Nowa Kodyfikacja Prawa Karnego, (XXIV), 229-234.

Neale, K. (1992). The European Prison Rules: Context, Philosophy and Issues. Prison Information Bulletin, (16), 4-6.

Nikołajew, J. (2013). Reguły Minimalne i Europejskie Reguły Więzienne a prawo więźniów do wolności sumienia i religii w Polsce [Minimum Rules and European Prison Rules and the Right of Prisoners to Freedom of Conscience and Religion in Poland]. Studia z Prawa Wyznaniowego, (16), 111-135.

Nowicki, M.A. (2009). Wokót konwencji europejskiej. Komentarz do Europejskiej Konwencji Praw Cztowieka [Around the European Convention. Commentary on the European Convention on Human Rights]. Warsaw: Wolters Kluwer.

Pawlak, K. (2007). Więzienia dla niepetnosprawnych fizycznie i psychicznie w Polsce $w$ okresie międzywojennym [Prisons for the physically and mentally disabled in Poland in the interwar period.]. In B. Skafiriak (Ed.), Pomoc postpenitencjarna $w$ kontekście strategii działań resocjalizacyjnych [Post-penitentiary assistance in the context of rehabilitation strategies ] (pp. 55-60). Kraków: Impuls.

Płatek, M. (1997). Europejskie Reguły Więzienne a polskie prawo i praktyka penitencjarna [European Prison Rules and Polish Penitentiary Law and Practice]. Studia Iuridica, (34), 167-186. 


\section{THE STANDARDS OF IMPRISONMENT IN PENITENTIARY ISOLATION...}

Płatek, M. (2008). Europejskie Reguły Więzienne z 2006 r. [European Prison Rules 2006]. Państwo i Prawo, (2), 3-17.

Podgórska-Jachnik, D. (2015). „Piss on Pity - Disability”. Odrzucenie litości doznawanej przez osoby niepetnosprawne jako przejaw ich dqżen emancypacyjnych [,Piss on Pity - Disability”. The rejection of the mercy experienced by people with disabilities as a manifestation of their emancipatory aspirations]. In T. Szkudlarek, A. Komorowska-Zielony (Eds.), Różnice, edukacja, inkluzja [Differences, education, inclusion]. Gdańsk: Wydawnictwo Uniwersytetu Gdańskiego.

Postulski, K. (2016). Kodeks karny wykonawczy. Komentarz [The Criminal Executive Code. Comments]. Warsaw: Wolters Kluwer.

Regulation of the Minister of Justice of 14 August 2003 on the manner of conducting penal interactions in penal institutions and detention centres. Journal of Laws No. 151, item 1469.

Regulation of the Minister of Justice of 2 May 1989 on the regulations governing the execution of sentences for imprisonment. Journal of Laws No. 31, item 166.

Rekomendacja Rec (2006)2 Komitetu Ministrów do państw członkowskich Rady Europy w sprawie Europejskich Reguł Więziennych (Przyjęta przez Komitet Ministrów w dniu 11 stycznia 2006 r. na 952 posiedzeniu delegatów) [Recommendation Rec (2006)2 of the Committee of Ministers to the Member States of the Council of Europe on the European Prison Rules (Adopted by the Committee of Ministers on 11 January, 2006 on the 952 Meeting of Delegates]. Retrieved from https://bip.sw.gov.pl/SiteCollectionDocuments/CZSW/prawaczl/document.pdf [accessed on 13.08.2019].

Resolution by the Sejm of the Republic of Poland of 1 August 1997 - Charter of Rights of Persons with Disabilities. M.P. of 1997, No. 50, item 475.

Rojek P. (2018). Areszty i zakłady karne nieprzystosowane dla niepełnosprawnych [Arrests and prisons not adapted for the disabled]. Prawo.pl: https://www.prawo.pl/prawo/areszty-i-zaklady-karnenieprzystosowane-dla-niepelnosprawnych,74632.html [accessed on 13.08.2019].

Sierpowska, I., \& Kogut, A. (2010), Status osoby niepetnosprawnej w polskim systemie prawa [The status of a disabled person in the Polish legal system]. Wrocław: Wydawnictwo Gaskor.

Środa, M. (1994). Idea godności [The idea of dignity]. Palestra, 38(7-8), 156-158.

Stahl, M. (2007). Cele publiczne i zadania publiczne [Public objectives and public tasks]. In J. Zimmermann (Ed.), Koncepcja systemu prawa administracyjnego. Zjazd Katedr Prawa Administracyjnego $i$ Postepowania Administracyjnego [The concept of the system of administrative law. Convention of the Chairs of Administrative Law and Administrative Proceedings] (pp. 95-116).Warsaw: Wolters Kluwer.

Standard Minimum Rules for the Treatment of Prisoners Adopted by the First United Nations Congress on the Prevention of Crime and the Treatment of Offenders, held at Geneva in 1955, and approved by the Economic and Social Council by its resolutions $663 \mathrm{C}$ (XXIV) of 31 July 1957 and 2076 (LXII) of 13 May 1977. Retrieved from https://www.unodc.org/pdf/criminal_ justice/UN_Standard_Minimum_Rules_for_the_Treatment_of_Prisoners.pdf [accessed on 13.08.2019].

Stanisławski, P. (2008). Cela bez taryfy ulgowej [Duties without concessionary fare]. Magazyn Integracja, 2. Retrieved from www.niepelnosprawni.pl/ledge/x/23374 [accessed on 3.07.2012]. 


\section{EASTERN EUROPEAN JOURNAL OF TRANSNATIONAL RELATIONS}

Szlęzak-Kawa, E. (2014). Niepełnosprawni też siedzą [The handicapped are also sitting]. Forum Penitencjarne, (11), 13-15.

Witkowska, C. (2016). Poczucie bezpieczeństwa oraz różnego rodzaju wsparcia wobec osób niepełnosprawnych intelektualnie jako kluczowe zadanie państwa [A sense of security and support for people with intellectual disabilities is a key task for the state]. Acta Scholae Superioris, 2(18), 91-109.

Zima-Parjaszewska, M., Wołowicz-Ruszkowska, A., Kurowski, K., Orzechowski, M. \& Buchholtz, A. (2015). Osoba z niepetnosprawnościq intelektualna w postępowaniach sqdowych i przed innymi organami. Poradnik praktyczny [A person with intellectual disabilities in court proceedings and before other authorities. Practical guide], Warsaw: Polskie Stowarzyszenie na Rzecz Osób z Upośledzeniem Umysłowym. 